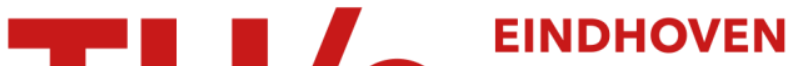 UNIVERSITY OF TECHNOLOGY
}

\section{On line system and analysis of standing and walking foot pressures in normals and leprosy patients}

\section{Citation for published version (APA):}

Patil, K. M., Babu, M., Oommen, P. K., Malaviya, G. N., \& Huson, A. (1995). On line system and analysis of standing and walking foot pressures in normals and leprosy patients. In S. K. Guha (Ed.), Proceedings of the $1 s t$ regional conference, IEEE Engineering in Medicine and Biology Society, and 14th conference of the Biomedical Engineering Society of India : an international meeting, February 15-18, 1995, New Dehli Institute of Electrical and Electronics Engineers.

Document status and date:

Published: 01/01/1995

\section{Document Version:}

Publisher's PDF, also known as Version of Record (includes final page, issue and volume numbers)

\section{Please check the document version of this publication:}

- A submitted manuscript is the version of the article upon submission and before peer-review. There can be important differences between the submitted version and the official published version of record. People interested in the research are advised to contact the author for the final version of the publication, or visit the $\mathrm{DOI}$ to the publisher's website.

- The final author version and the galley proof are versions of the publication after peer review.

- The final published version features the final layout of the paper including the volume, issue and page numbers.

Link to publication

\section{General rights}

Copyright and moral rights for the publications made accessible in the public portal are retained by the authors and/or other copyright owners and it is a condition of accessing publications that users recognise and abide by the legal requirements associated with these rights.

- Users may download and print one copy of any publication from the public portal for the purpose of private study or research.

- You may not further distribute the material or use it for any profit-making activity or commercial gain

- You may freely distribute the URL identifying the publication in the public portal.

If the publication is distributed under the terms of Article $25 \mathrm{fa}$ of the Dutch Copyright Act, indicated by the "Taverne" license above, please follow below link for the End User Agreement:

www.tue.nl/taverne

Take down policy

If you believe that this document breaches copyright please contact us at:

openaccess@tue.nl

providing details and we will investigate your claim. 


\section{K.M. Patil, M. Babu+, P.K. Oommen ${ }^{++}$, G.N. Malaviya*, A Huson@ and L.H. Braak"}

Department of Applied Mechanics, + Dept. of Electrical Engineering, II.T., Madras, ++ CLTRI, Chengalpattu, * CJL Agra, @ Department of Movement Sciences, University of Limburg, \# Dept. of Mechanical Engineering, Eindhoven University of Technology, Eindhoven, The Netherlands.

\section{ABSTRACT}

In this work presented here, a new barographic on-line métinod of measurement of standing and walking foot pressures is presented. This method is used to find a new characteristic which could clearly distinguish the normal foot pressure distributions from the abnormal distributions such as those occurring in leprosy subjects with sensory and muscle paralysis and in different stages of foot deformities.

Key words: On-line system, Leprosy, foot pressures, contact ratio index

\section{INTRODUCTION}

Foot pressure measurement systems reported in literature [l] present variations of foot pressures only on one foot and they do not have enough resolution to show foot pressure variations on certain areas of the foot prone to ulcer formation or tarsal disintegration. In leprosy as well as in neuropathic feet of diabetic patients, since both the feet could be affected, it is necessary to have foot pressure measurements made on both the feet, simultaneously during standing and one after another during walking for at least two steps, such that it could help in detecting changes in both the feet pressures. In this work presented here, to fulfil the above objective, a new barographic on-line method of measurement of standing and walking foot pressures, is presented. This method is used to analyse foot pressure data of a large number of normal and leprosy patients very quickly so that it could help in finding a new characteristic that could distinguish the normal foot pressures and different stages of progression of foot deformities occurring in leprosy subjects with sensory and muscle paralysis.

\section{METHOD}

The measurement technique involves use of a long barograph (capabie of accommodating at least two steps during walking) for foot image formation, a video camera for image capturing, video digitizer for digitizing the image and load cells for recording load variations during standing and walking. The barograph [2] consists of a long and thick glass plate $(1.8 \mathrm{~m} \times 0.45 \mathrm{~m} \mathrm{x}$ $0.0125 \mathrm{~m}$ ), illuminated at the two opposing (longitudinal) edges by fluorescent lights and covered by a thin sheet of soft white plastic upon which the subject stands or walks. The image is formed on the barograph due to scattering of light at the areas of contact of the foot. When viewed from a $45^{\circ}$ inclined mirror placed below the glass plate, the areas of foot contact are reflected as intensities which are proportional to applied pressure. The reflected image is captured by a monochrome video camera and is digitized using MVP AT video digitizer.

The foot images as the person stands or walks are processed by using an image processing software, specially developed for on-line measurement at the Biomedical Engineering Division, I.I.T., Madras. The principle of image processing involves first capturing the background image of the barograph before the person stands or walks and subtracting this image from the images of the soles of the feet obtained during standing or walking, respectively. A threshold function is applied to the subtracted image to black out the noise caused by background change due to light smearing by foot and relative motion between the sheet and the glass plate. As the barograph is mounted on load cells, a module in the programme calculates the load acting on the barograph at the instant of image grabbing. An interactive rectangular windowing provision is also incorporated in the software to define windows around the individual foot images so that force-area pressure plots for each foot are obtained separately. Now; by using a software specially developed for the on-line measurements, the load data and image data are converted, using dynamic calibration procedure, to show frame by frame variations of maximum forces acting on the foot, maximum areas of contact of the foot with the barograph and variations of maximum foot pressures during walking. By switching to the combined image facility, pseudo colour image of the feet, representing the zones of highest pressures developed during walking cycle, are observed on the computer screen. The other facilities developed during walking are path of centres of pressures and velocity of walking. The off-line facilities include scanning of time variation of pressures at different regions of the foot. The program also is capable of showing on-line variations of standing foot pressures (in different areas of the foot) in pseudo colour form.

In leprosy with sensory paralysis it is found [1] that the foot subjected to moderate pressures and longer duration is more harmful (in causing ulcers) than the one subjected to high pressures for short duration. Therefore, a new index known as contact ratio index (which takes care of magnitude and duration of peak pressures and the weight of the person) is used to distinguish the dangerous foot pressure characteristics, (which possibly cause foot ulcers and deformities in leprosy) from the normal characteristics. The contact ratio index (CRI), found by scanning the specified area of the foot for the variation of pressures with time is defined as

$$
C R I=100 \%\left[\frac{t P}{T W}\right]
$$

$t$ - duration to which $50 \%$ of the peak pressure is acting on the specified area of foot, $\mathrm{T}$ - total contact time of the same foot, $\mathrm{P}-50 \%$ of the peak pressure in the specified area of the foot, W- weight of the foot.

\section{RESULTS}

The results of standing foot pressures are found to be highly reproducible when measured at different times of the day. Figs. (1) and (2), respectively show the equipressure contour distributions in different parts of the foot for a normal and leprosy patient with both feet anaesthetic, having swelling and pain in right ankle joint. The peak normal standing foot pressures are of the order of $10 \mathrm{~N} / \mathrm{cm}^{2}$, of the same order as reported in literature [1]. The foot pressure analysis, on leprosy subject (with deformity of the foot) during standing, show that there is abrupt change in pressure distribution from one zone to another zone of equipressure colour contours and these are concentrated in small areas, whereas the corresponding variations in normal subjects are found to be smooth and spread over larger areas of the foot.

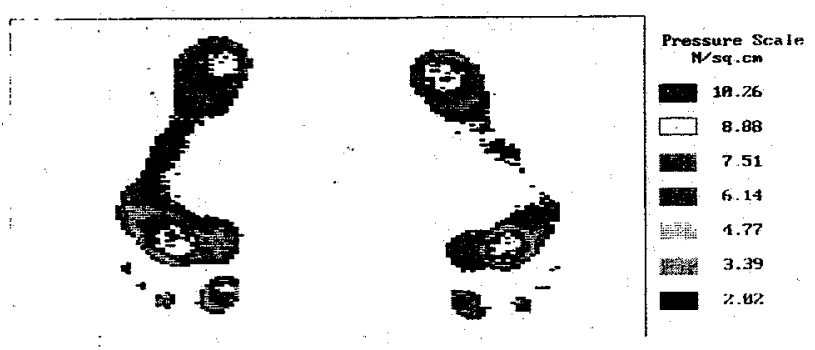

Fig. 1 Standing foot iso-pressure plots for a normal subject

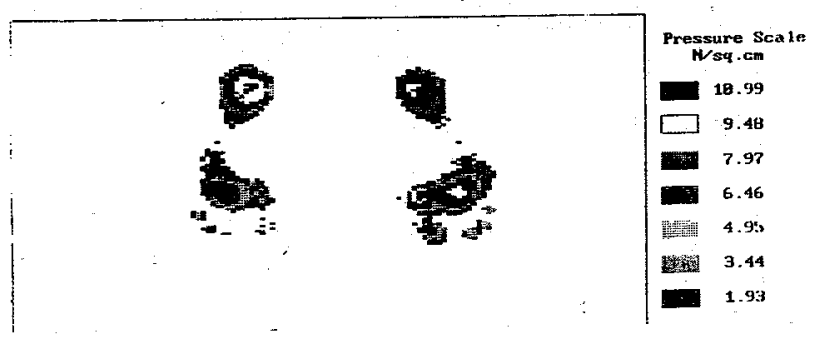

Fig. 2 Standing foot iso-pressure plots for a leprosy subject

Fig. (3) shows the time variations of maximum foot pressures, forces and areas of contact of the foot for a normal subject during each frame of walking for both the feet, separately. The locations of peak pressures and path of centre of pressures are also shown in the same figure. The corresponding variations of 
maximum foot pressures for a leprosy subject, with intrinsic, sensory and dorsiflexor muscle paralysis of the left collapsed arch, are shown in Fig. (4). The zones of maximum pressures (magnitude being same order for normals as reported in [1]) developed, during the walking cycle for both the feet, are shown for normal and the above leprosy subject in Figs. (5) and (6), respectively. The path of the centre of foot pressure is found to be a smooth curve for normals whereas it follows a zigzag path for leprosy subject. The peak pressure for leprosy subject shown here are of lower magnitude (in the left collapsed arch of the foot) than the normat pressure. But this pressure in that part of the foot is exerted for a higher duration as shown in Fig. (7).
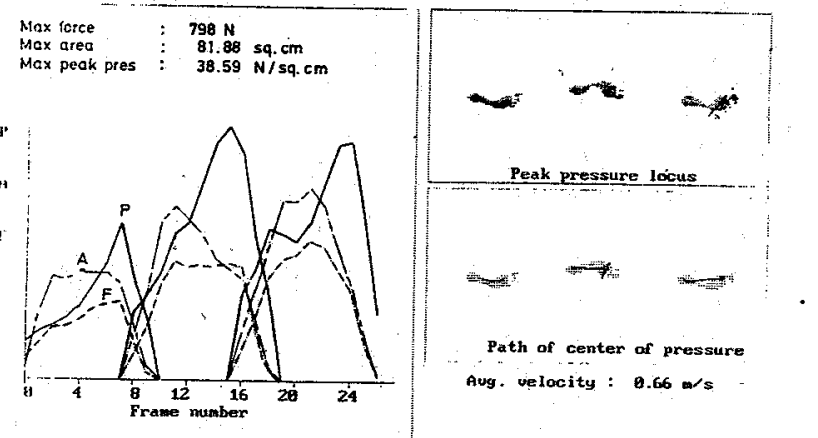

Fig. 3 Maximum walking foot pressures, forces, areas of foot contact for a normal subject

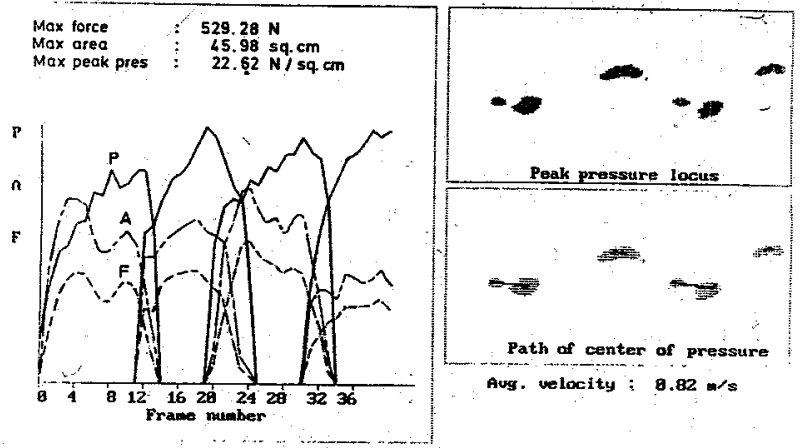

Fig. 4 Maximum walking foot pressures, forces, areas of foot contact for a leprosy subject

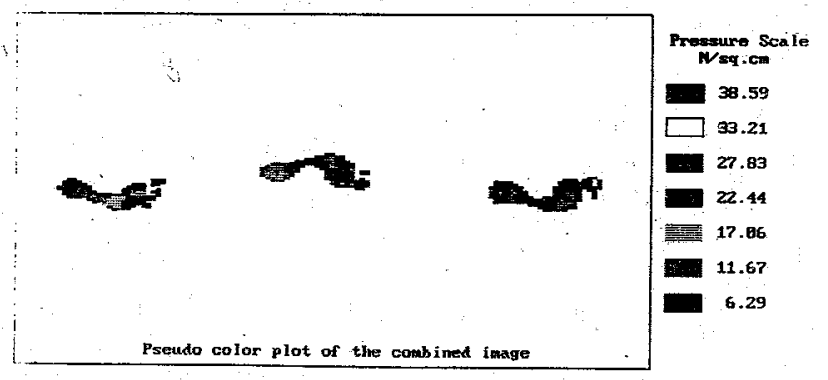

Fig. 5 Zonal variations of maximum foot pressures during walking for the nornal subject

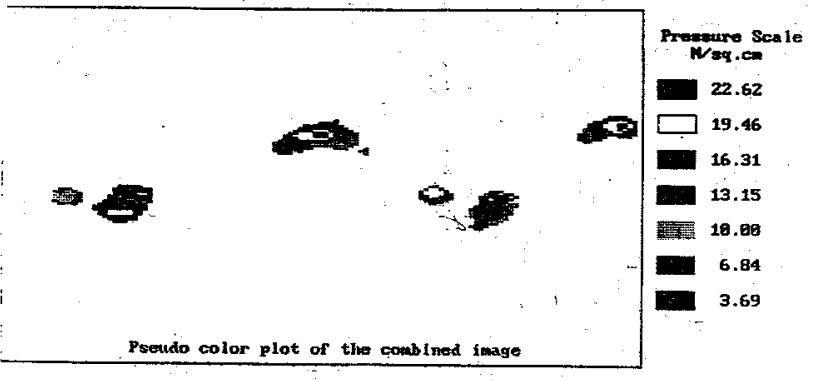

Fig. 6 Zonal variations of maximum foot pressures during walking for the leprosy subject

To take into account pressure magnitude along with its duration a new index known as contact ratio index (defined earlier) is calculated for different areas of the foot by scanning respective areas of the foot (Fig. (7)) for variations of pressures with time. Fig. (7) shows the variation of foot pressures with time for a leprosy subject on her left foot with sensory, intrinsic and dorsiflexor muscle paralysis and in the collapsed foot region of the foot (due to tarsal disintegration). The foot is divided into ten regions (Fig. (8)) and scanned for: maximum foot pressure variation in these regions. The contact ratio indices (CRI) are calculated for a number of normal and leprosy patients in different stages of the progress of the disease such as (11) early stage, characterised by clawing of toes and or intrinsic paralysis, (I2) intermediate or second stage with severe clawing of toes and (13) advanced stage involving, bone in fore foot damaged after severe clawing of toes or absorption of toes. Mean values of the contact ratio indices (CRI) are calculated by statistical analysis (with $95 \%$ percent confidence level) for the above groups in the ten areas of the foot and are presented in Fig. (8). The CRI variations are found to be able to distinguish the normals from leprosy patients in different stages of progress of the disease.
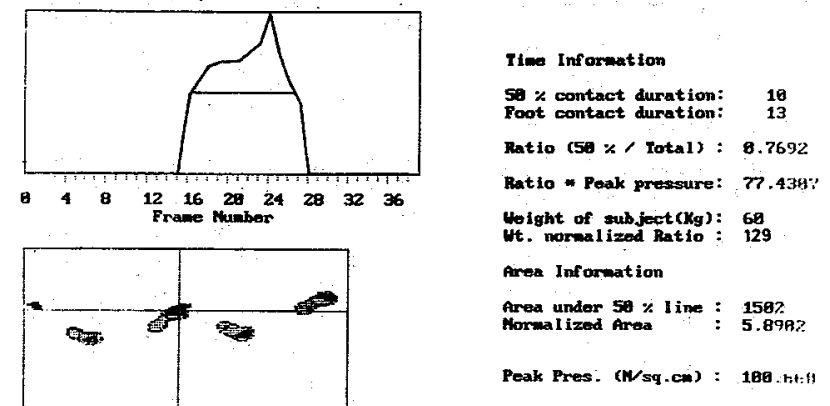

Fig. 7 Walking foot pressure in the collapsed arch region for ansecond leprosy patient

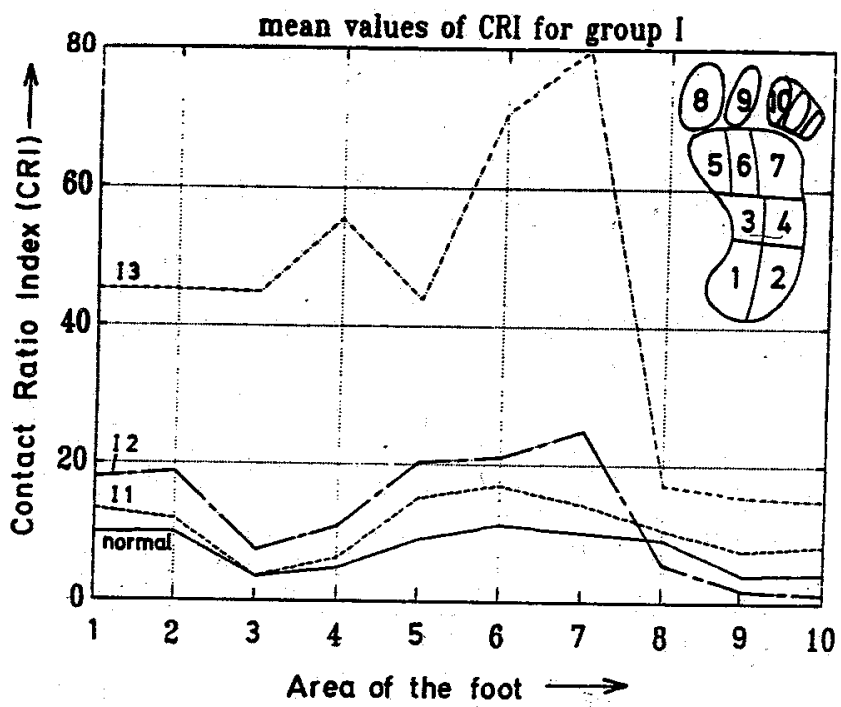

Fig. $8 \mathrm{CRI}$ in ten regions of feet for nomals and leprosy patients in different stages of progress of disease

\section{DISCUSSION}

The on-line method of measurement and analysis of foot pressures is able to quickly analyse a number of normal and leprosy patient feet with high resolution. The new characteristics (CRI) holds the promise to help in detecting the early changes taking place giving rise to bone changes and later to tarsal disintegration. This possibly will help orthopaedic surgeons to take early preventive measures to protect the feet from further damage.

\section{ACKNOWLEDGEMENT}

The authors are very grateful to Mr. M.A. Kiel of Eindhoven University of Technology, Eindhoven for the statistical analysis of CRI of normal and leprosy patients. The authors are also grateful to DST, Governmont of India; Eindhoven University of Technology and University of Limburg for financial grants for the above project.

\section{REFERENCES}

[1] Lord M, Reynolds DP and Hughes JR (1986) "Foot pressure measurement: a review of clinical findings" $J$ of Biomed. Engg., 8, 283-294.

[2] Patil KM and Srinath MS (1990) "New image processing system for analysis, display and measurement of static and dynamic foot pressures" Med. \& Biol. Eng. \& Comput, 28, 416-422. 